56) L. S. Darken, R. W. Gurry, "Physical Chemistry of Metals” p.437 (1953), McGraw Hill, N.Y.
57) W. Jost, "Diffusion in Solids, Liquids and Gases" p.436 (1960), Academic Press, N.Y.

\title{
Studies on Nitrides Formation by Means of Nitrogen Plasma Jet (Part 2)
}

\author{
Osamu Matsumoto, Yoshiaki ShIRAto and Yasumasa HAYAKAWA \\ Department of Chemistry, College of Science and Engineering, \\ Aoyama Gakuin University Megurisawa-machi, Setagaya-ku, Tokyo
}

Received Jan. 231970

\begin{abstract}
Nitrides formation by the reaction between the nitrogen plasma jet and tablets made of metal oxides such as $\mathrm{Al}_{2} \mathrm{O}_{3}, \mathrm{TiO}_{2}$ and $\mathrm{ZrO}_{2}$, and graphite powder were studied. $\mathrm{AlN}$, TiN and $\mathrm{ZrN}$ were formed. The mixing ratio of graphite to oxides affected the yield of nitrides formation. Intermediates as nonstoichiometric oxides and oxycarbides were identified. The overall reaction may be carried out by the reaction
\end{abstract}

$$
\mathrm{MO}_{\mathrm{x}}+\mathrm{xC}+\mathrm{nN} \rightarrow \mathrm{MN}_{\mathrm{n}}+\mathrm{xCO}
$$

The nitriding of zirconium silicate in the same way as nitrization of oxides was studied and $\mathrm{ZrN}$ was formed.

\section{Introduction}

In the previous paper, ${ }^{1}$ the apparatus and experimental procedures for this study and nitrides formations by the reaction between respective metals and the nitrogen plasma jet with use of a transferred type plasma torch were described.

In this paper, nitrides formation by the reaction between respective oxides and the nitrogen plasma jet in the same way as the previous paper ${ }^{1)}$ were reviewed.

\section{Nitrides Formation by Nitrization of Oxides}

Various nitrides such as $\mathrm{AlN}^{2}$ ),3), $\mathrm{TiN}^{4)}$ and
$\mathrm{ZrN}^{5}$ ) were formed by the reaction between respective oxide-graphite tablet acting as an anode and the nitrogen plasma jet with use of the reaction apparatus as shown previously ${ }^{1)}$.

The nitriding of $\mathrm{Al}_{2} \mathrm{O}_{3}$ by nitrogen was carried out as in the following equation.

$$
\mathrm{Al}_{2} \mathrm{O}_{3}+3 \mathrm{C}+\mathrm{N}_{2} \rightarrow 2 \mathrm{AlN}+3 \mathrm{CO}
$$

This process was previously planned to fix nitrogen ${ }^{6)}$ and was known as Haglund process. If this process could be carried out effectively, the hopeful application of a plasma jet will be expected. The direct nitridings of oxides by the nitrogen plasma jet were also examined.

In this chapter, experimental procedures, 


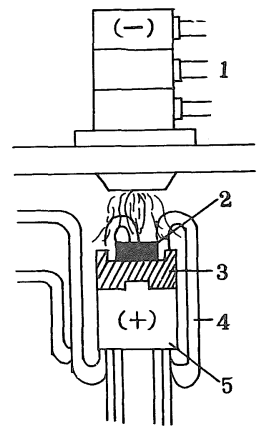

1: Plasma torch 2: tablet 3: Graphite block 4: Cu coil 5: Cu crucible

Fig. 1 Reaction apparatus for nitriding of oxide-graphite tablet

results and the discussion of the reaction of nitrides formation by nitriding various oxides with the nitrogen plasma jet and by nitriding zirconium silicate with the nitrogen plasma jet were reviewed.

\subsection{Experimental procedures}

2.1.1 Apparatus The apparatus for the reaction was described previously. The specimen tablet was set on the graphite block placed on the copper anode as shown in Fig. 1. The arc was formed between the tungsten cathode in the torch and the graphite block. The apparatus for a measurement of temperature and conformations of products were described previously ${ }^{1}$.

2.1.2 Experimental methods The formation of nitrides was carried out in the same way as described previously ${ }^{1)}$. The products were confirmed by an X-ray diffraction, chemical analysis, infrared absorption and electron diffraction.

\subsection{Formation of Aluminum Nitride by Nitriding Aluminum Oxide ${ }^{2), 3)}$}

2.2.1 Temperature measurement: The surface temperature of the tablet and the graphite block under the nitrogen plasma jet were measured with a micro-pyrometer. The relation between the surface temperature and the current intensity at various nitrogen flow

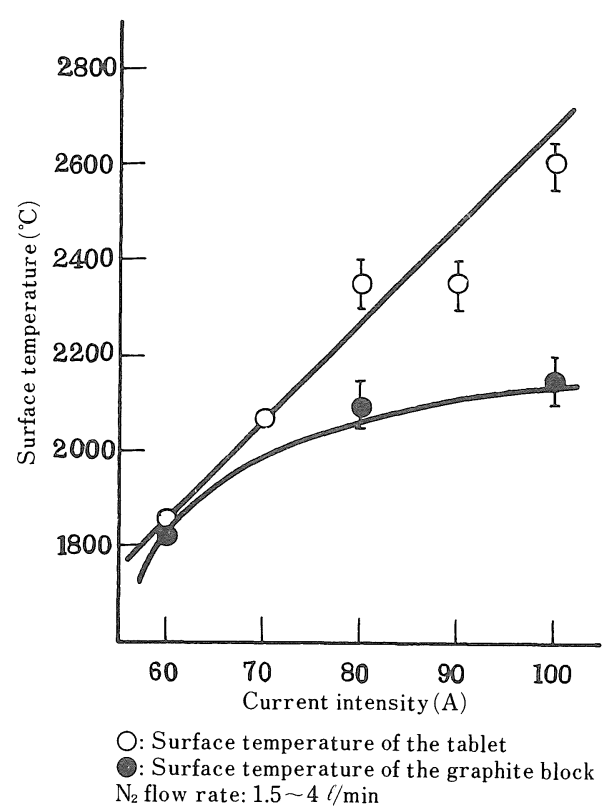

Fig. 2 Relation between surface temperature of tablet and the current intensity

rates is shown in Fig. 2. The surface temperature of the tablet raised with increasing current intensity and was higher than the melting point of $\mathrm{Al}_{2} \mathrm{O}_{3}$.

2.2.2 Confirmation of products When the nitrogen plasma jet reacted with the tablet, greyish powder was deposited on the graphite, on the coil and the wall of the chamber. The greyish cake was also formed on the graphite block.

Each product was confirmed by an X-ray diffraction and chemical analysis. Typical $\mathrm{X}$-ray diffraction patterns are sown in Fig. 3. The product deposited on the graphite block was confirmed to be AIN, while the cake formed on the graphite was AlN containing an unreacted $\mathrm{Al}_{2} \mathrm{O}_{3}$ and graphite. The product deposited on the coil and the wall of the chamber were amorphous.

2.2.3 Influence of the mixing ratio of carbon to $\mathrm{Al}_{2} \mathrm{O}_{3}\left(\mathrm{C} / \mathrm{Al}_{2} \mathrm{O}_{3}\right)$ The influence of $\mathrm{C} / \mathrm{Al}_{2} \mathrm{O}_{3}$ to the reaction is shown in Fig. $4^{* 1}$.

* 1 In Fig. 4, Al conversion rate $(A l C . R$.$) is$ defined as follows, $A l C . R$. $=$ [ ( $\mathrm{Al}$ as $\mathrm{AlN}$ in product $(\mathrm{g})$ (Al as $\mathrm{Al}_{2} \mathrm{O}_{3}$ in original tablet $(\mathrm{g}))] \times 100(\%)$ 


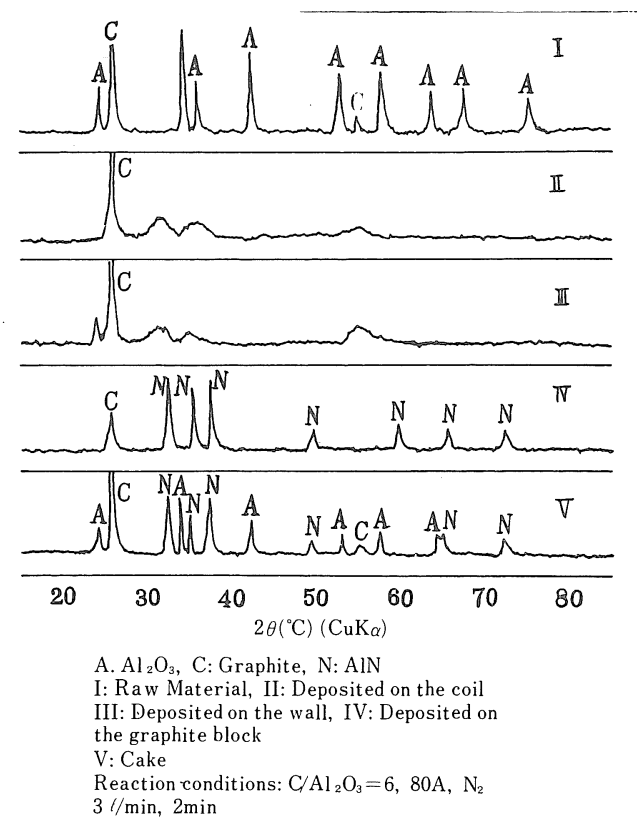

Fig. 3 X-ray diffraction patterns of deposited materials

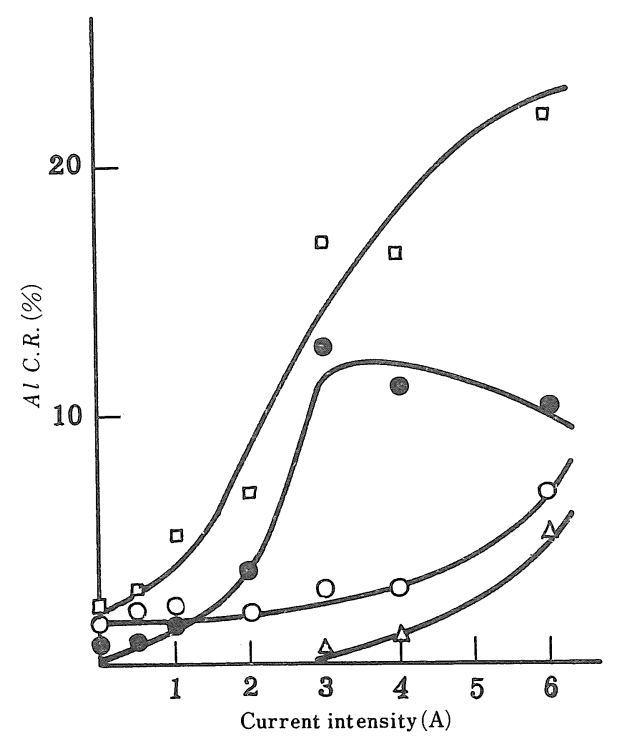

O: Coil and Wall, O: Graphite block

$\triangle$ : Cake, $\square$ :Total amount

Reaction conditions: $80 \mathrm{~A}, \mathrm{~N}_{2} 3 \ell / \mathrm{min}, 2 \mathrm{~min}$

Fig. 4 Relation between Al C.R. and $\mathrm{C} / \mathrm{Al}_{2} \mathrm{O}_{3}$

The AlC.R. of the product on the coil and of the cake formed on the graphite block increased gradually with increasing a $\mathrm{C} / \mathrm{Al}_{2} \mathrm{O}_{3}$, while that of the product deposited on the graphite block

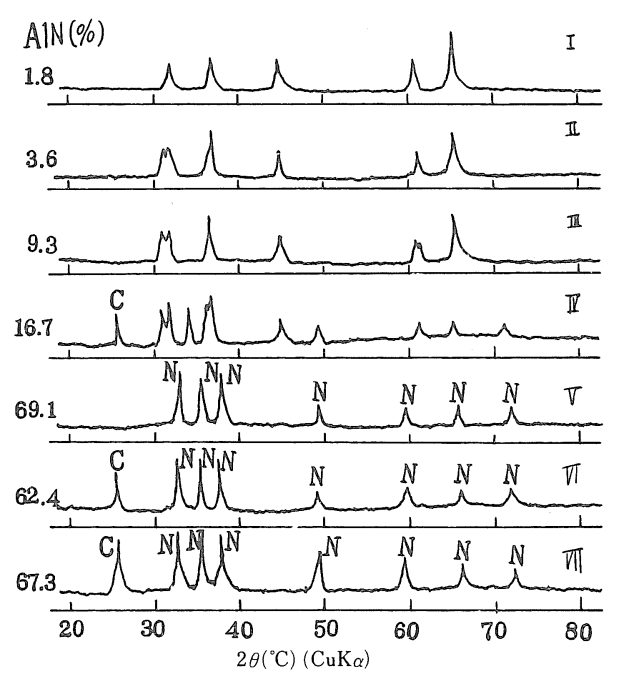

C: Graphite, N: AlN,

C/ $\mathrm{Al}_{2} \mathrm{O}_{3}$ : I: 0 , II: 0.5 , III: 1, IV $2, \mathrm{~V}: 3, \mathrm{VI}: 4$, VII: 6

Fig. 5 X-ray diffraction patterns obtained for various $\mathrm{C} / \mathrm{Al}_{2} \mathrm{O}_{3}$

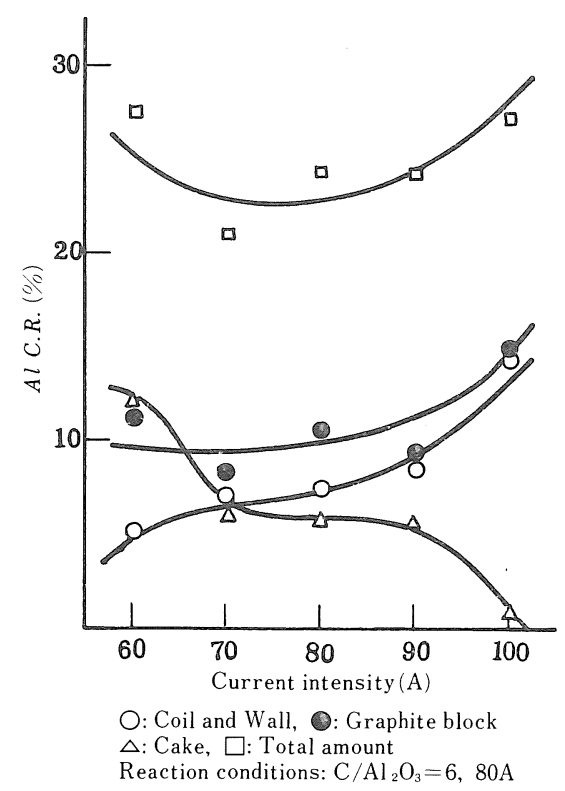

Fig. 6 Relation between $A l$ C.R. and the current intensity

increased with increasing $\mathrm{C} / \mathrm{Al}_{2} \mathrm{O}_{3}$ up to $\mathrm{C} / \mathrm{Al}_{2} \mathrm{O}_{3}=3$.

X-ray diffraction patterns of products deposited on the graphite. block at different ratio of $\mathrm{C} / \mathrm{Al}_{2} \mathrm{O}_{3}$ are shown in Fig. 5 . When $\mathrm{C} / \mathrm{Al}_{2} \mathrm{O}_{3}$ exceeded 3 , main product was 
AlN. AlN contents obtained by a chemical analysis are also shown in Fig. 5. From these results the reaction seemed to proceed rapidly at $\mathrm{C} / \mathrm{Al}_{2} \mathrm{O}_{3}$ larger than 3 .

\subsubsection{Influence factors on the formation} of AIN Influences of various conditions such as the current intensity, the nitrogen flow rate and the reaction time to the formation of $\mathrm{A} 1 \mathrm{~N}$ were also examined.

The relation between $A l$ C.R. and the current intensity is shown in Fig. 6. Al C.R. of the cake on the graphite block decreased with increasing current intensity, while that of products deposited on other parts kept nearly constant even if the current intensity was varied.

The relation between $A l C$ C.R. and the nitrogen flow-rate is shown in Fig. 7. Al C.R. of the cake on the graphite block linearly decreased with increasing the nitrogen flow rate, while that of products deposited on other parts gradually increased with increasing the nitrogen flow rate.

The relation between $A l \quad C . R$. and the reaction time is shown in Fig. 8. Al C.R. of the cake on the graphite block was kept nearly constant regardless the reaction time. On the

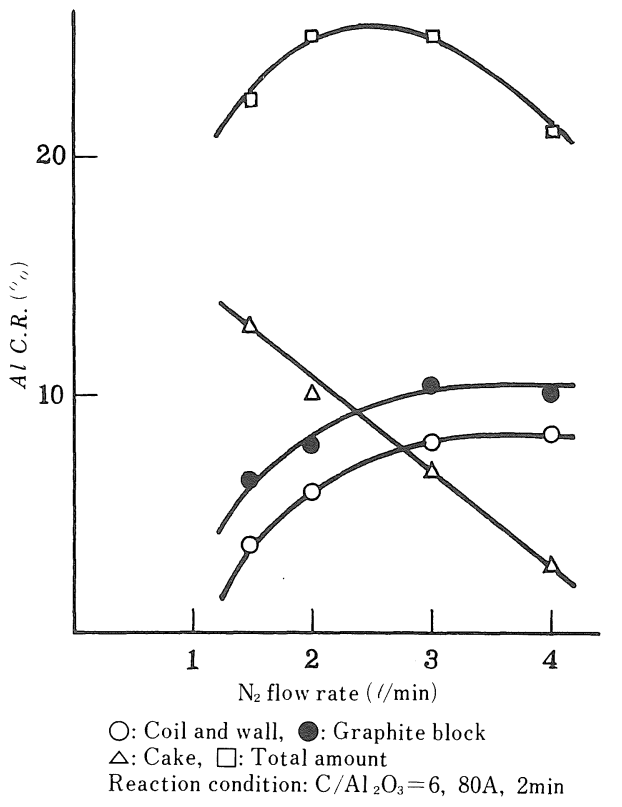

Fig. 7 Relation between $A l C . R$. and the nitrogen flow rate

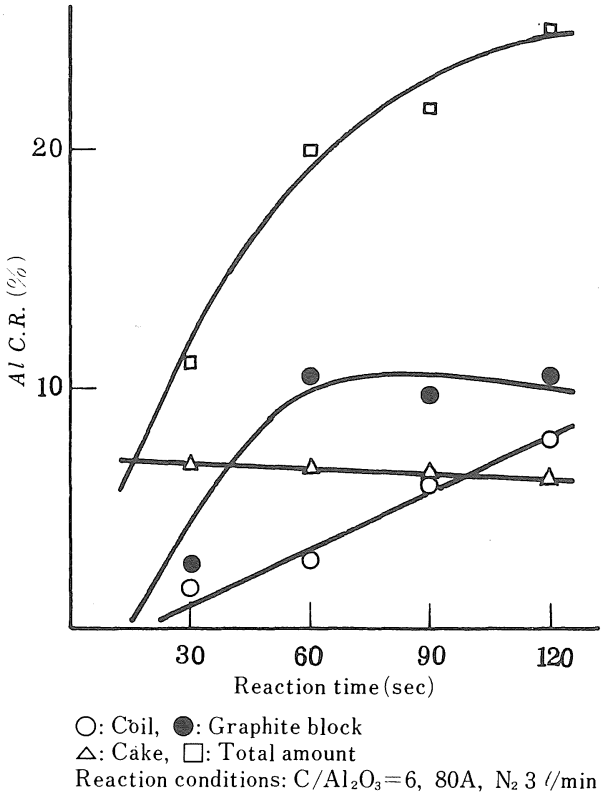

Fig. 8 Relation between $A l C . R$. and the reaction time
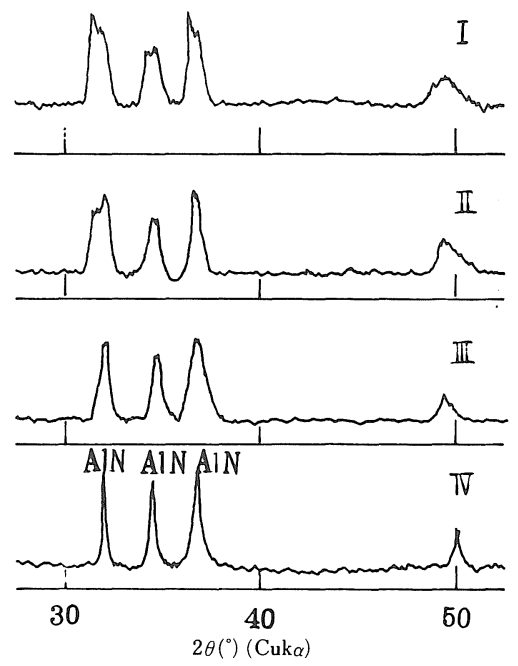

Reaction: I: $15 \mathrm{sec}$, II: $30 \mathrm{sec}$, III: $60 \mathrm{sec}$, IV: $120 \mathrm{sec}$ Reaction conditions: $\mathrm{C} / \mathrm{Al}_{2} \mathrm{O}_{3}=6,80 \mathrm{~A}, \mathrm{~N}_{2} 31 / \mathrm{min}$

Fig. 9 X-ray diffraction patterns of products sampled from the surface of the cake at various reaction times

other hand, that of the product deposited on the coil increased with increasing reaction time and that of the product deposited on the coil increased with increasing reaction time and that of the product deposited on the graphite block increased with increasing reaction time up to 60 
Table 1 Relation between the reaction time and AlN formation on the tablet surface

\begin{tabular}{c|c|c}
\hline \hline $\begin{array}{c}\text { Reaction time } \\
(\mathrm{sec})\end{array}$ & $\begin{array}{c}\text { Sample weight } \\
(\mathrm{g})\end{array}$ & $\begin{array}{c}\text { AlN content } \\
(\%)\end{array}$ \\
\hline 15 & 0.110 & 19.0 \\
30 & 0.125 & 25.3 \\
60 & 0.134 & 24.3 \\
120 & 0.141 & 21.2 \\
\hline
\end{tabular}

Reaction condition: $\mathrm{C} / \mathrm{Al}_{2} \mathrm{O}_{3}=6,80 \mathrm{~A}, 3 \mathrm{l} / \mathrm{min}$ sec.

Substances on the surface of the cake formed on the graphite block were examined by an X-ray diffraction and chemical analysis. Results obtained are shown in Fig. 9 and Table 1 , which indicate that the crystallization of AlN proceeds, with the reaction time.

2.2.5 Discussion of AlN formation As mentioned previously ${ }^{1}$, the nitrogen plasma jet is supposed to consist in mainly atomic nitrogen. Heavy heating by the plasma jet will cause the melting of $\mathrm{Al}_{2} \mathrm{O}_{3}$. In the melt, $\mathrm{Al}_{2} \mathrm{O}_{3}$ reacted with carbon and might be reduced to a lower oxidation state (such as $\mathrm{A} 1 \mathrm{O}, \mathrm{Al}_{2} \mathrm{O}$ or oxycarbide) ${ }^{8)}$. AlN formation will proceed through the reaction between atomic nitrogen and these intermediates.

Since AlN begins to sublimate above

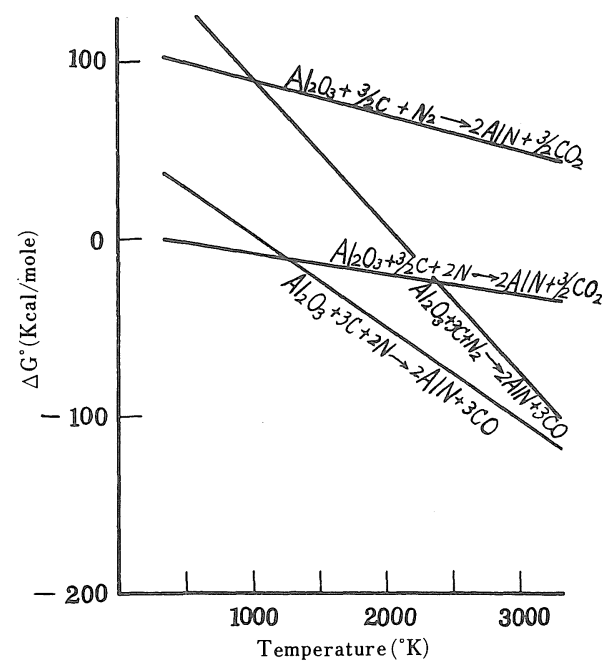

Fig. 10 Relation between $\Delta G^{\circ}$ of the reaction of AlN formation and temperature $\left.2,000^{\circ} \mathrm{C}^{9}\right)$, AlN formed on the surface of the tablet would sublimate a deposite on the copper coil, on the wall of the chamber and on the graphite block. The product on the copper coil and on the wall of the chamber may be cooled suddenly and thus deposited as an amorphous state, while that deposited on the graphite block may be cooled gradually and crystal was formed.

The mixing ratio of carbon to $\mathrm{Al}_{2} \mathrm{O}_{3}$ $\left(\mathrm{C} / \mathrm{Al}_{2} \mathrm{O}_{3}\right)$ was very effective to AlN formation. The temperature dependence of the free energy change was calculated for the probable reaction of $\mathrm{AlN}$ formation ${ }^{10}$ ) and are shown in Fig. 10. From Fig. 10 and experimental results, the formation of AlN at $3,000^{\circ} \mathrm{K}$ may be carried out by the following reaction,

$$
\mathrm{Al}_{2} \mathrm{O}_{3}(l)+3 \mathrm{C}+2 \mathrm{~N} \rightarrow 2 \mathrm{AlN}+3 \mathrm{CO} .
$$

\subsection{Formation of Zirconium Nitride Nitriding Oxide ${ }^{5}$ )}

2.3.1 Temperature measurement The surface temperature of $\mathrm{TiO}_{2}$-graphite mixture tablet and the graphite block under the nitrogen plasma jet was measured with a micro-pyrometer. The relation between the surface temperature and the current intensity at various nitrogen flow rates is shown in Fig. 11.

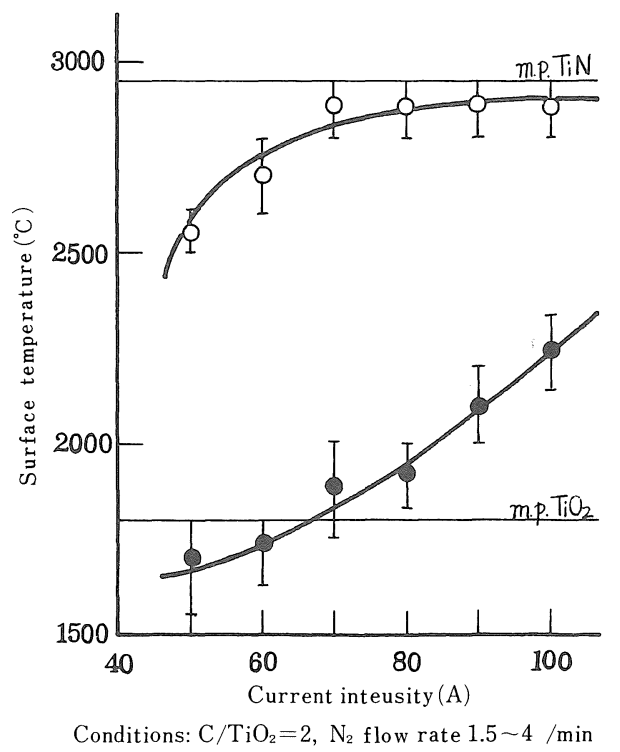

Fig. 11 Relation between the surface temperature of $\mathrm{TiO}_{2}$-graphite tablet and current intensity 
The surface temperature of the tablet raised with increasing current intensity and was higher than the melting point of $\mathrm{TiO}_{2}$.

\subsubsection{Confirmation of product When} nitrogen plasma jet reacted with the tablet, a black powder was deposited on the copper coil and on the wall of the chamber. The metallic cake was formed on the graphite block. Typical X-ray diffraction patterns are shown in Fig. 12. In the powder deposited on the copper coil and the wall of the chamber, only graphite was observed. The cake formed on the graphite block was confirmed to be almost TiN.
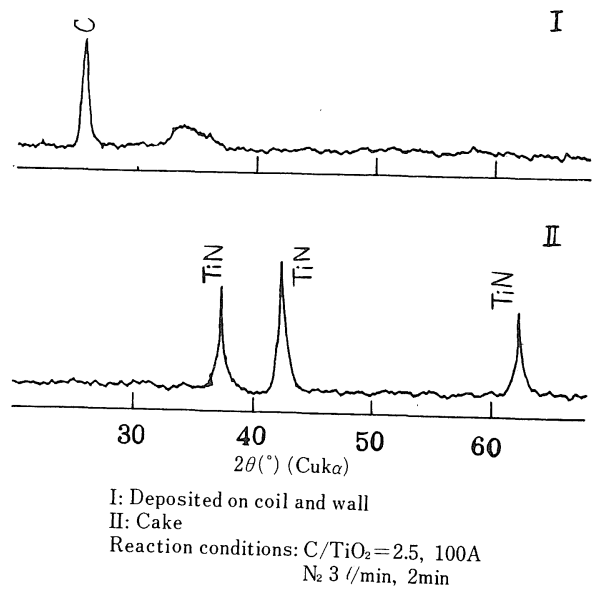

Fig. 12 X-ray diffraction patterns of deposited material by nitriding of $\mathrm{TiO}_{2}$

2.3.3 Influence of the mixing ratio of carbon to $\mathrm{TiO}_{2} \quad\left(\mathrm{C} / \mathrm{TiO}_{2}\right)$ The influence of $\mathrm{C} / \mathrm{TiO}_{2}$ to the reaction is shown in Fig. 13*. The $\mathrm{Ti}$ C.R. increased with increasing $\mathrm{C} / \mathrm{TiO}_{2}$ up to 2 or 2.5 . When $\mathrm{C} / \mathrm{TiO}_{2}$ exceeded 2 or $2.5, \mathrm{Ti}$ $C . R$. decreased with increasing $\mathrm{C} / \mathrm{TiO}_{2}$ and was maximum at $\mathrm{C} / \mathrm{TiO}_{2}=2$ or 2.5 under various current intensities.

$\mathrm{X}$-ray diffraction patterns of the cake formed on the graphite block at $\mathrm{C} / \mathrm{TiO}_{2}=0.5 \sim$ 5 are shown in Fig. 14. In the case of $\mathrm{C} / \mathrm{TiO}_{2} \leqq 2$

* In Fig. 13, Ticonversion rate (Ti C.R.) is defined as follows, Ti C.R. $=[(\mathrm{Ti}$ as $\mathrm{TiN}$ in product $(\mathrm{g})) /\left(\mathrm{Ti}\right.$ as $\mathrm{TiO}_{2}$ in original tablet (g)) ] $\times 100(\%)$

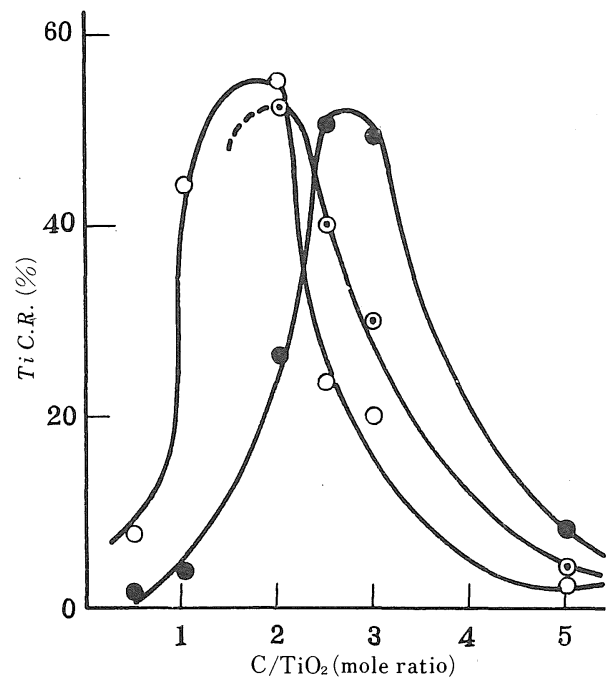

O: $50 \mathrm{~A}, \bigcirc: 80 \mathrm{~A}, \odot: 100 \mathrm{~A}$

Reaction conditions: $\mathrm{N}_{2} 3 / / \mathrm{min}, 2 \mathrm{~min}$

Fig. 13 Relation between Ti C.R. and $\mathrm{C} / \mathrm{TiO}_{2}$
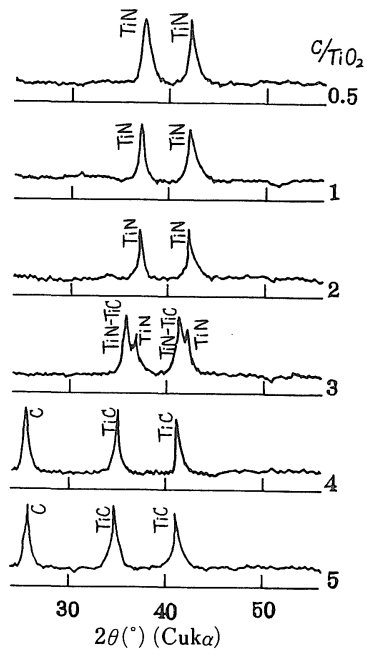

Reaction conditions: $80 \mathrm{~A}, \mathrm{~N}_{2} 3 \ell$ $\min , 2 \mathrm{~min}$

Fig. 14 X-ray diffraction patterns of cake obtained by various $\mathrm{C} / \mathrm{TiO}_{2}$

Inain product was $\mathrm{TiN}$, and $\mathrm{C} / \mathrm{TiO}_{2}$ exceeded 3 main product was $\mathrm{TiC}$. In the case of $\mathrm{C} / \mathrm{TiO}_{2}=$ 2.5 TiN and TiN-TiC solid solution were formed. Nitrogen and carbon contents in the product obtained by chemical analysis are listed in Table 2. Nitrogen content was maximum at $\mathrm{C} / \mathrm{TiO}_{2}=2$ or 2.5. From these results, the reaction seems to 
Table 2 Chemical analy sis results of products by nitriding of $\mathrm{TiO}_{2}$ for various $\mathrm{C} / \mathrm{TiO}_{2}$

\begin{tabular}{c|c|c|c}
\hline $\mathrm{C} / \mathrm{TiO}_{2}$ & $\mathrm{~N}(\%)$ & Combined C (\%) & Free C (\%) \\
\hline 0.5 & 9.76 & 4.91 & 3.34 \\
1.0 & 11.8 & 3.91 & 3.82 \\
2.0 & 16.7 & 0.58 & 2.25 \\
2.5 & 10.8 & 5.58 & 0.58 \\
3.0 & 7.94 & 8.08 & 1.78 \\
5.0 & 0.33 & 14.6 & 22.0 \\
\hline
\end{tabular}

Reaction condition: $80 \mathrm{~A}, \mathrm{~N}_{2} 3 l / \mathrm{min}, 2 \mathrm{~min}$

proceed rapidly at $\mathrm{C} / \mathrm{TiO}_{2}=2$ or 2.5 .

\subsubsection{Influence factors on the formation of} TiN Influences of various conditions such as the current intensity, nitrogen flow rate and reaction time to the formation of $\mathrm{TiN}$ were examined.

The relation between $T i$ C.R. and the current intensity is shown in Fig. 15. In the case of $\mathrm{C} / \mathrm{TiO}_{2}=2 \mathrm{Ti}$ C.R. was almost constant even if the current intensity was varied, and in the case of $\mathrm{C} / \mathrm{TiO}_{2}=2.5 \mathrm{Ti}$ C.R. decreased with increasing the current intensity up to $70 \mathrm{amp}$. When the current intensity was more $\tan 80 \mathrm{amp}$. Ti C.R. gradually increased with the current intensity. In the case of $\mathrm{C} / \mathrm{TiO}_{2}=2$ the main product was almost $\mathrm{TiN}$ even if the current

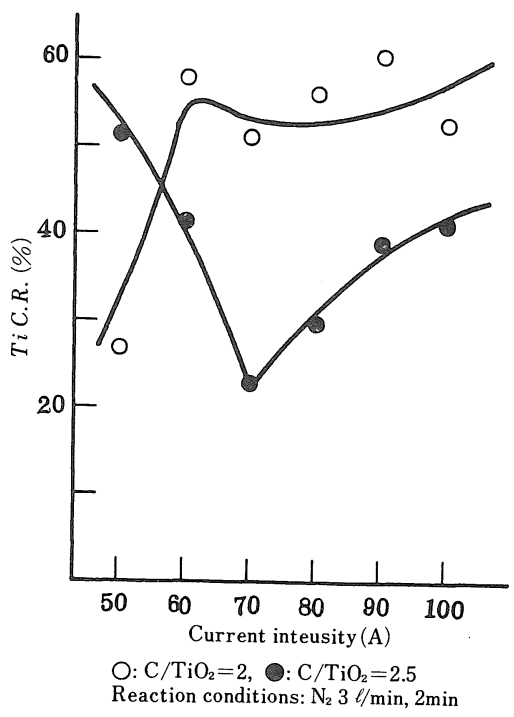

Fig. 15 Relation between Ti C.R. and current intensity intensity was changed. At the current intensity of 50 amp., $\mathrm{Ti}_{2} \mathrm{O}_{3}$ was formed.

The relation between $T i$ C.R. and the nitrogen flow rate is shown in Fig. 16, and $T i$ C.R. decreased with increasing the nitrogen flow

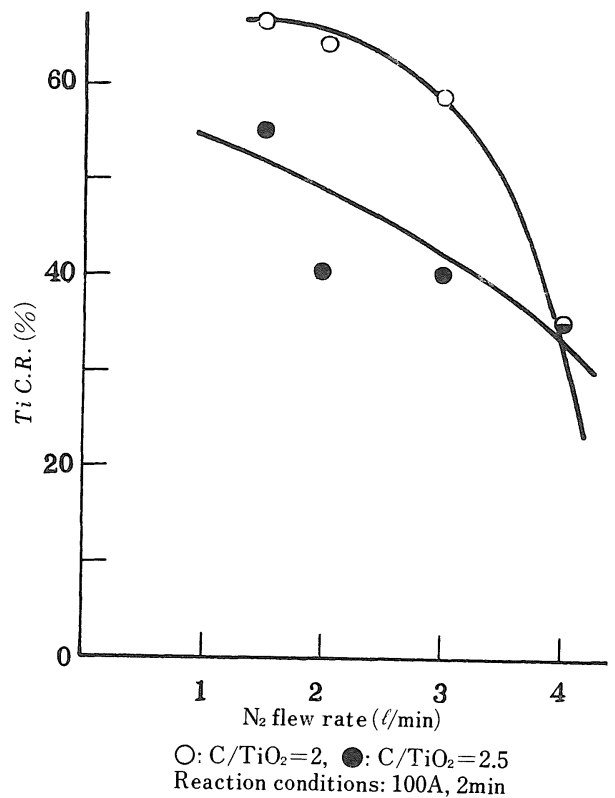

Fig. 16 Relation between $T i C . R$. and $\mathrm{N}_{2}$ flow rate

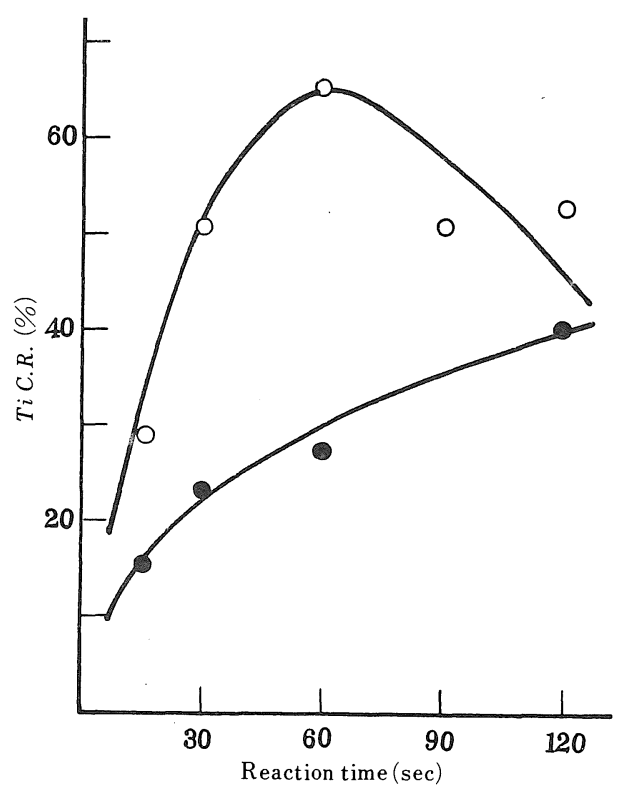

O: $\mathrm{C} / \mathrm{TiO}_{2}=2$, $\mathrm{C} / \mathrm{TiO}_{2}=2.5$

Reaction conditions: $100 \mathrm{~A}, 3 \ell / \mathrm{min}$

Fig. 17 Relation between Ti C.R. and the reaction time 
Table 3 Free energy change of carbon reduction and nitriding reaction of titanium oxides

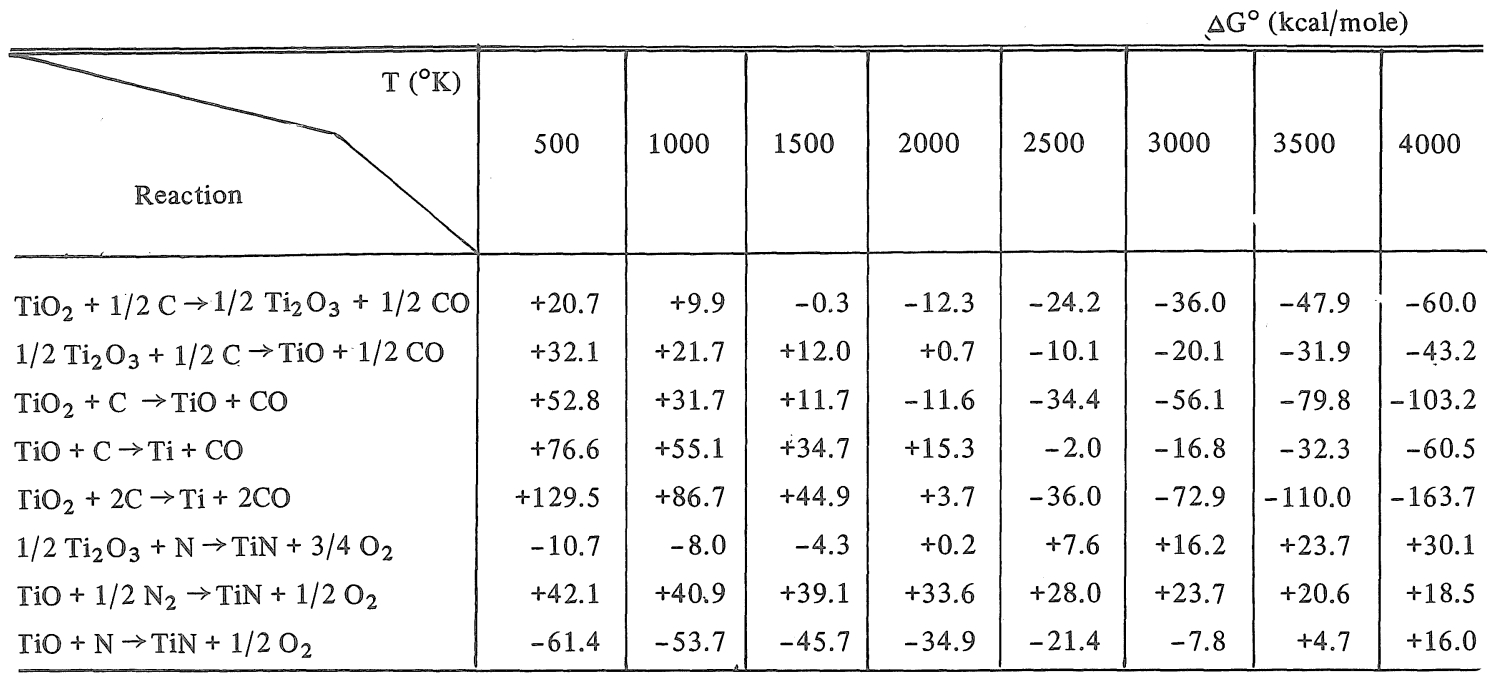

rate.

The relation between $T i$ C.R. and the reaction time is shown in Fig. 17 . When $\mathrm{C} / \mathrm{TiO}_{2}$ $=2 \mathrm{Ti}$ C.R. was maximum at $60 \mathrm{sec}$, and when $\mathrm{C} / \mathrm{TiO}_{2}=2.5 \mathrm{Ti}$ C.R. gradually increased with increasing the reaction time. In both cases, when the reaction time was shorter than $30 \mathrm{sec}$., TiO was observed in the products.

2.3.5 Discussion of $\mathbb{T i N}$ formation The surface temperature of the tablet under the nitrogen plasma jet was higher than the melting point of $\mathrm{TiO}_{2}$, and $\mathrm{TiO}_{2}$ was a liquid state. In the melt, $\mathrm{TiO}_{2}$ reacted with carbon and should be reduced to a lower oxidation state. Intermediates such as $\mathrm{Ti}_{2} \mathrm{O}_{3}$ and $\mathrm{TiO}$ were identified in the product. The reaction might be carried out through these intermediate states.

In case of the nitriding $\mathrm{TiO}_{2}$ with $\mathrm{NH}_{3}{ }^{11}$ ), the reaction was carried out through the reduction of $\mathrm{TiO}_{2}$ to $\mathrm{TiO}$ and $\mathrm{TiN}$ formed by nitriding TiO with $\mathrm{NH}_{3}$.

The temperature dependency of the free energy change of the reduction of $\mathrm{TiO}_{2}$ with carbon and the nitriding of titanium oxides with atomic nitrogen ${ }^{10}$ ) are listed in Table $3 . \mathrm{TiO}_{2}$ should be reduced with carbon to $\mathrm{TiO}$ thermodynamically. The nitriding $\mathrm{TiO}$ with atomic nitrogen might be more probable than the reduction of $\mathrm{TiO}$ to $\mathrm{Ti}$ with carbon.
The nitridings of $\mathrm{TiO}^{*}$ and $\mathrm{Ti}_{2} \mathrm{O}_{3}{ }^{*}$ by the nitrogen plasma jet were examined and results obtained are shown in Fig. 18, TiN was formed by the reaction between $\mathrm{TiO}$ and the nitrogen plasma jet.

From these results mentioned above, the nitriding of $\mathrm{TiO}_{2}$ by nitrogen plasma jet should

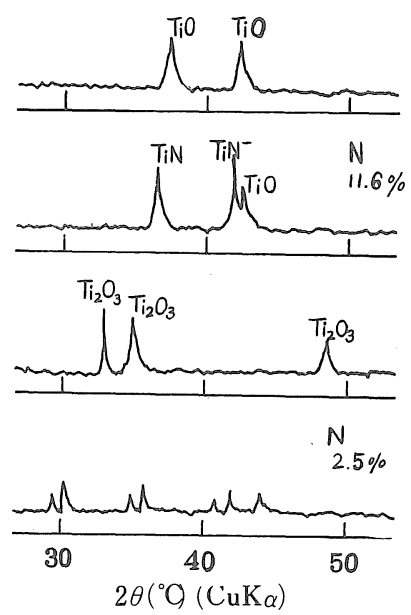

Reaction conditions: $100 \mathrm{~A}, \mathrm{~N}_{2}$ $3 \ell / \min , 2 \min$

Fig. $18 \mathrm{X}$-ray diffraction patterns of products by the nitriding of $\mathrm{TiO}$ and $\mathrm{Ti}_{2} \mathrm{O}_{3}$

* TiO and $\mathrm{Ti}_{2} \mathrm{O}_{3}$ were made by oxidation of titanium with argon-oxygen plasma jet ${ }^{12}$ ) 
be carried out through the following steps : i) the reduction of $\mathrm{TiO}_{2}$ to $\mathrm{TiO}$ with carbon, and ii) the nitriding of $\mathrm{TiO}$ with atomic nitrogen.

The temperature dependency of the free energy change for probable overall reaction of TiN formation are shown in Fig. 19. From Fig. 19 and the experimental results, the formation of TiN was carried out at about $3,000^{\circ} \mathrm{K}$ by the reaction,

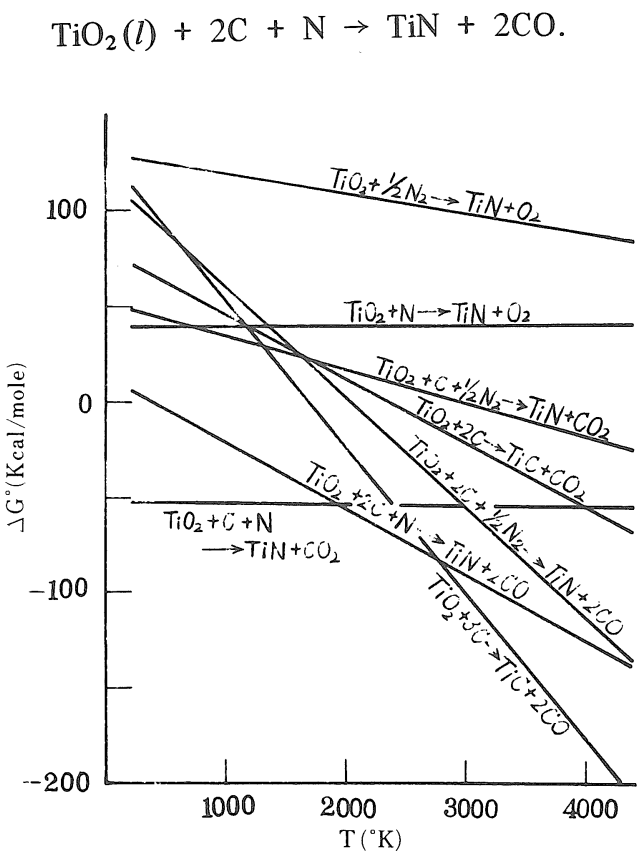

Fig. 19 Relation between $\Delta \mathrm{G}^{\circ}$ of the reaction of $\mathrm{TiN}$ formation and temperature

\subsection{Formation of Zirconium Nitride by Nitriding Oxide ${ }^{5)}$}

2.4.1 Temperature measurement The surface temperature of the $\mathrm{ZrO}_{2}$-graphite mixture tablet and a graphite block under the nitrogen plasma jet was measured with a micro-pyrometer. The relation between the surface temperature and the current intensity at various nitrogen flow rate is shown in Fig. 20. The surface temperature of the tablet raised with increasing current intensity and was higher than the melting point of $\mathrm{ZrO}_{2}$.

2.4.2 Confirmation of product When the nitrogen plasma jet reacted with the tablet, the

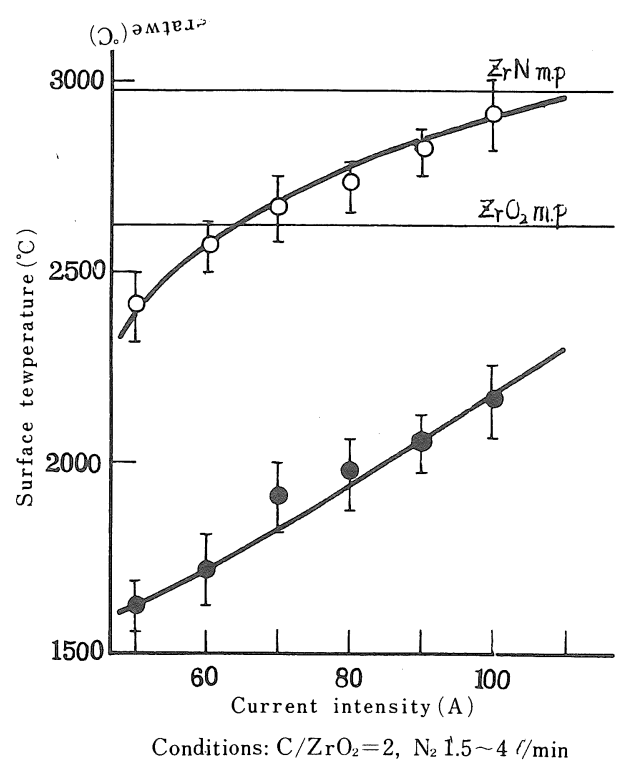

Fig. 20 Relation between the surface temperature of $\mathrm{ZrO}_{2}$-graphite tablet and current intensity

metallic cake was only formed on the graphite block. It was confirmed to be almost $\mathrm{ZrN}$ from $\mathrm{X}$-ray diffraction data.

2.4.3 Influence of the mixing ratio of carbon to $\mathrm{ZrO}_{2} \quad\left(\mathrm{C} / \mathrm{ZrO}_{2}\right)$ The influence of

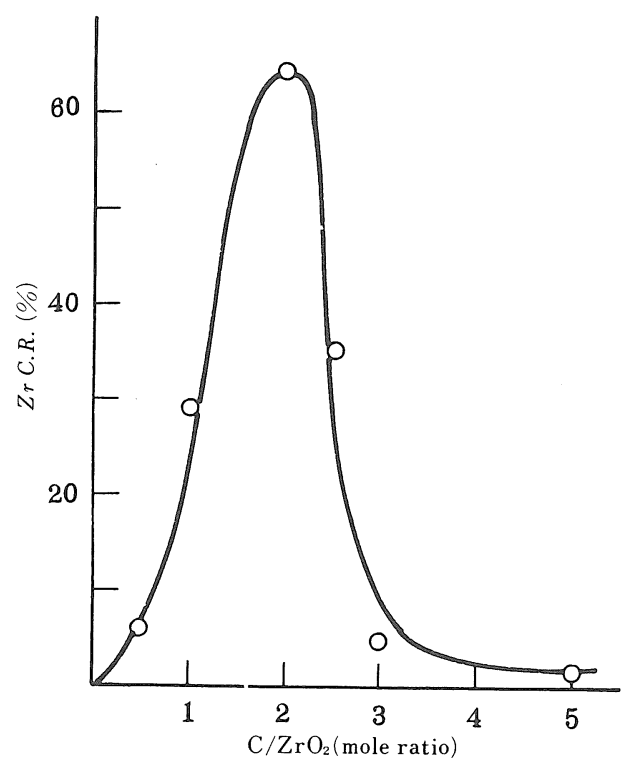

Reaction conditions: $100 \mathrm{~A}, \mathrm{~N}_{2} 3 / / \mathrm{min}, 1 \mathrm{~min}$

Fig. 21 Relation between $\mathrm{Zr} C . R$. and $\mathrm{C} / \mathrm{ZrO}_{2}$ 


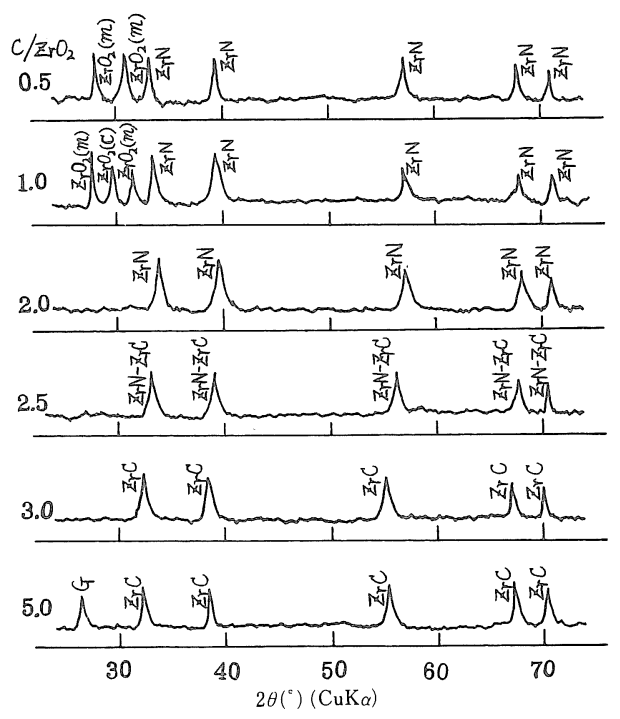

Reaction conditions: $100 \mathrm{~A}, \mathrm{~N}_{2} 3 / / \mathrm{min}, 2 \mathrm{~min}$

Fig. $22 \mathrm{X}$-ray diffraction patterns of products obtained by various $\mathrm{C} / \mathrm{ZrO}_{2}$

$\mathrm{C} / \mathrm{ZrO}_{2}$ to the reaction is shown in Fig. 21*. The $\mathrm{Zr} C . R$. decreased with increasing $\mathrm{C} / \mathrm{ZrO}_{2}$ up to 2. When $\mathrm{C} / \mathrm{ZrO}_{2}$ exceeded 2, $\mathrm{Zr}$ C.R. decreased with increasing $\mathrm{C} / \mathrm{ZrO}_{2}$, and $\mathrm{Zr} C . R$. was maximum at $\mathrm{C} / \mathrm{ZrO}_{2}=2$.

$\mathrm{X}$-ray diffraction patterns of the cake formed on the graphite block at $\mathrm{C} / \mathrm{ZrO}_{2}=0.5 \sim$ 5 are shown in Fig. 22. When $\mathrm{C} / \mathrm{ZrO}_{2} \leqq 2$ main product was $\mathrm{ZrN}$, and when it exceeded 3 main product was $\mathrm{ZrC}$. The solid solution of $\mathrm{ZrN}$ and $\mathrm{ZrC}$ was formed at $\mathrm{C} / \mathrm{ZrO}_{2}=2.5$. Nitrogen and

Table 4 Chemical analysis results of products by nitriding of $\mathrm{ZrO}_{2}$ for various $\mathrm{C} / \mathrm{ZrO}_{2}$

\begin{tabular}{c|c|c|c}
\hline \hline $\mathrm{C} / \mathrm{ZrO}_{2}$ & $\mathrm{~N}(\%)$ & Combined C (\%) & Free C (\%) \\
\hline 0.5 & 3.26 & 0.40 & 0.76 \\
1.0 & 4.24 & 0.69 & 0.46 \\
2.0 & 7.05 & 1.31 & 0.45 \\
2.5 & 3.95 & 4.69 & 1.21 \\
3.0 & 0.96 & 9.85 & 1.45 \\
5.0 & 0.24 & 11.3 & 12.2 \\
\hline
\end{tabular}

Reaction condition: $100 \mathrm{~A}, \mathrm{~N}_{2} 3 \mathrm{l} / \mathrm{min}, 2 \mathrm{~min}$

* In Fig. 21, $\mathrm{Zr}$ conversion rate $(\operatorname{Zr} C . R$.$) is$ defined as follows, $\mathrm{Zr} . C \cdot R .=[(\mathrm{Zr}$ as $\mathrm{ZrN}$ in product $(\mathrm{g})) /\left(\mathrm{Zr}\right.$ as $\mathrm{ZrO}_{2}$ in original tablet $(\mathrm{g}))]$ x $100(\%)$ carbon contents in the product obtained by chemical analysis are listed in Table 4. Nitrogen content was maximum at $\mathrm{C} / \mathrm{ZrO}_{2}=2$. From these results, the reaction seems to proceed rapidly at $\mathrm{C} / \mathrm{ZrO}_{2}=2$.

\subsubsection{Influence factors on the formation of} $\mathbb{Z r N}$ Influences of various conditions such as the current intensity, the nitrogen flow rate and the reaction time to the formation of $\mathrm{ZrN}$ were examined.

The relation between $Z r \quad C . R$. and the current intensity at $\mathrm{C} / \mathrm{ZrO}_{2}=2$ is shown in Fig. 23.Zr. C.R. increased with increasing the current intensity. When the current intensity exceeded 80 amp., $\mathrm{Zr} C . R$. was independent of the change of the current intensity. When the current intensity, was lower than 60 amp., identified compounds in the products were $\mathrm{ZrN}$, cubic $\left.\left.\mathrm{ZrO}_{2}{ }^{13}\right), 14\right)$ and monoclinic $\mathrm{ZrO}_{2}$ which was a starting material. When the current intenstiy exceeded $70 \mathrm{amp}$. the product was almost $\mathrm{ZrN}$.

The relation between $Z r \quad C . R$. and the nitrogen flow rate is shown in Fig. 24. $\mathrm{Zr}$ C.R. was almost constant even if the nitrogen flow rate was varied. When the nitrogen flow rate was smaller than $2 \mathrm{l} / \mathrm{min}, \mathrm{ZrN}$ and cubic $\mathrm{ZrO}_{2}$ were found in the products. However, the product was

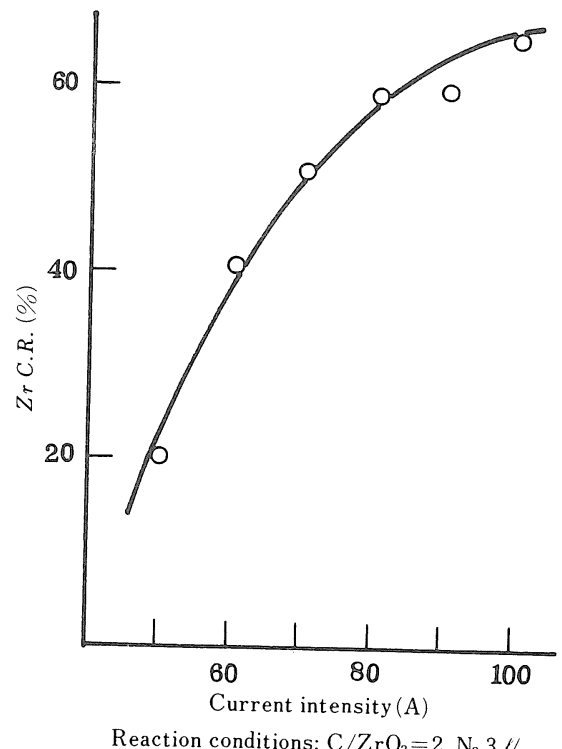
$\min , 1 \mathrm{~min}$

Fig. 23 Relation between $Z r$. C.R. and current intensity 


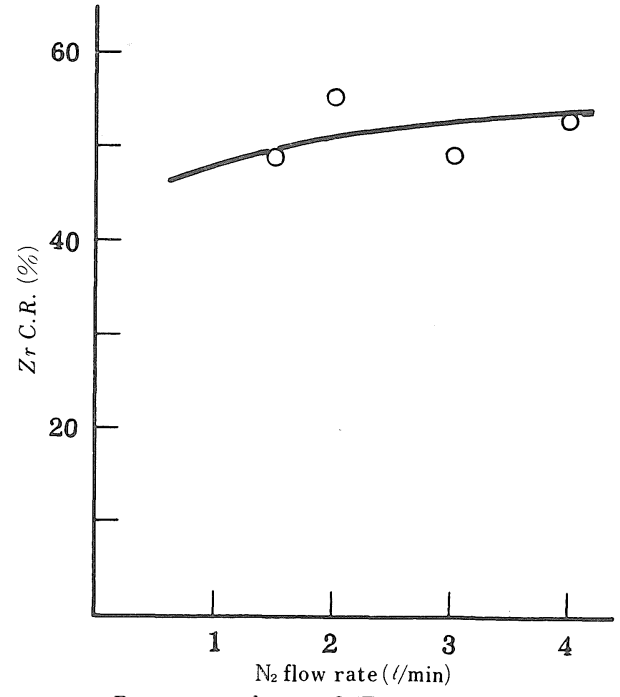

Reaction conditions: $\mathrm{C} / \mathrm{ZrO}_{2}=2,100 \mathrm{~A}, 1 \mathrm{~min}$

Fig. 24 Relation between $\mathrm{Zr}$ C.R. and $\mathrm{N}_{2}$ flow rate

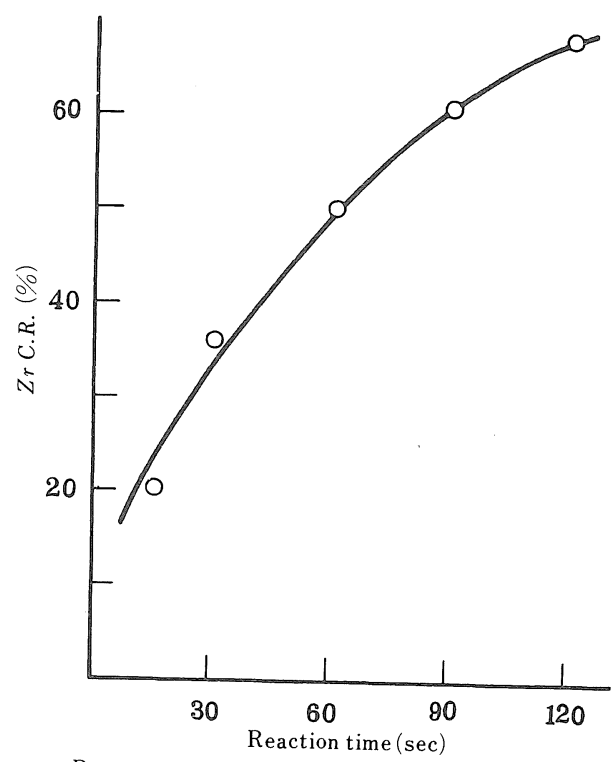

Reaction conditions: $\mathrm{C} / \mathrm{ZrO}_{2}=2,100 \mathrm{~A}, \mathrm{~N}_{2} 3 \ell \mathrm{min}$

Fig. 25 Relation between $\mathrm{Zr}$ C.R. and the reaction time

almost $\mathrm{ZrN}$ when the nitrogen flow rate was more than $3 \mathrm{l} / \mathrm{min}$.

The relation between $Z r C . R$. and the reaction time is shown in Fig. 25. $\mathrm{Zr}$ C.R. increased with the increasing reaction time. $X$-ray
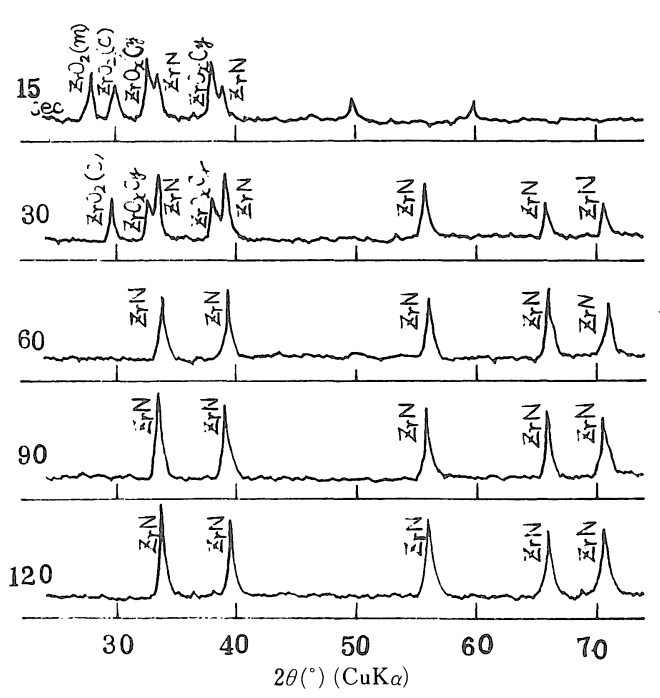

Reaction conditions: $\mathrm{C} / \mathrm{ZrO}_{2}=2, \mathrm{~N}_{2} 3 \ell / \mathrm{min}, 100 \mathrm{~A}$

Fig. 26 X-ray diffraction patterns of products obtained by various reaction time

diffraction patterns of the product by different reaction time are shown in Fig. 26. $\mathrm{ZrN}$ was already formed at $15 \mathrm{sec}$. from the beginning of reaction and when the reaction time was shorter than $30 \mathrm{sec}$. the cubic $\mathrm{ZrO}_{2}$ and the monoclinic $\mathrm{ZrO}_{2}$ which was the starting material were contained. Diffraction lines based on an fcc crystal, $2 \theta$ of which were lower than those of $\mathrm{ZrN}$ were found in the products. It was identified as zirconium oxycarbide in the form of $\mathrm{ZrO}_{\mathrm{x}} \mathrm{C}_{\mathrm{y}}{ }^{15}$ )

2.4.5 Discussion of $\mathrm{ZrN}$ formation The surface temperature of the tablet under the nitrogen plasma jet was higher than the melting point of $\mathrm{ZrO}_{2}$, and $\mathrm{ZrO}_{2}$ was a liquid state. In the melt, $\mathrm{ZrO}_{2}$ reacted with carbon and should be a more reactive state than $\mathrm{ZrO}_{2}$. At the beginning of the reaction intermediates such as $\mathrm{ZrO}_{2}$ and oxycardides, $\mathrm{ZrO}_{\mathrm{x}} \mathrm{C}_{\mathrm{y}}$, were identified in the product. The reaction should be carried out through these intermediate states. Combined carbon contents were relatively high in the product that contained cubic $\mathrm{ZrO}_{2}$ and $\mathrm{ZrO}_{\mathbf{x}} \mathrm{C}_{\mathbf{y}}$. Cubic $\mathrm{ZrO}_{2}$ was considered as zirconium oxynitride ${ }^{16}$ ). It is considered that molten $\mathrm{ZrO}_{2}$ reacted with carbon or atomic nitrogen and these intermediates were formed. Then atomic nitrogen would react with these intermediates 


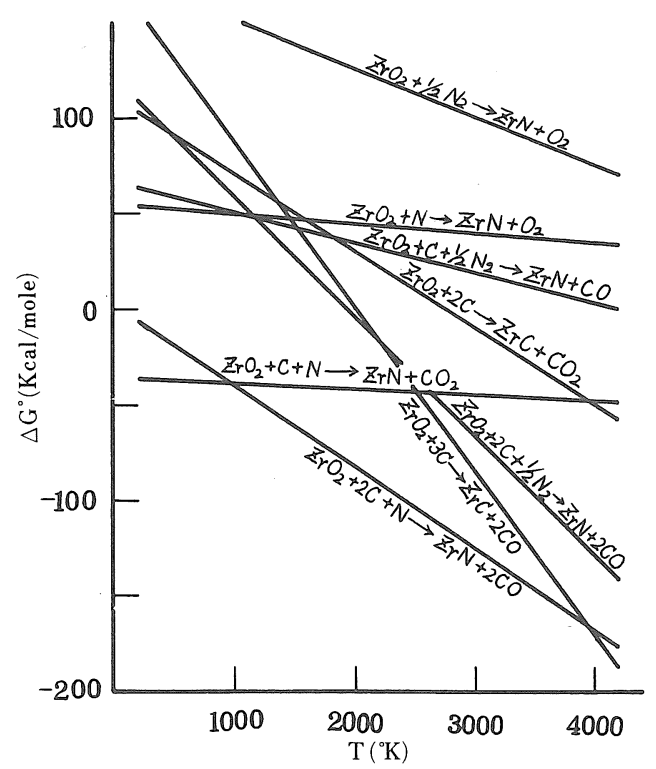

Fig. 27 Relation between $\Delta \mathrm{G}^{\circ}$ of the reaction of $\mathrm{ZrN}$ formation and the temperature

and $\mathrm{ZrN}$ was formed.

The temperature dependence of the free energy change for probable overall reaction of $\mathrm{ZrN}$ formation ${ }^{9)}$ are shown in Fig. 27. From Fig. 27 and the experimental results, the formation of $\mathrm{ZrN}$ at about $3,000^{\circ} \mathrm{K}$ was carried out through the reaction,

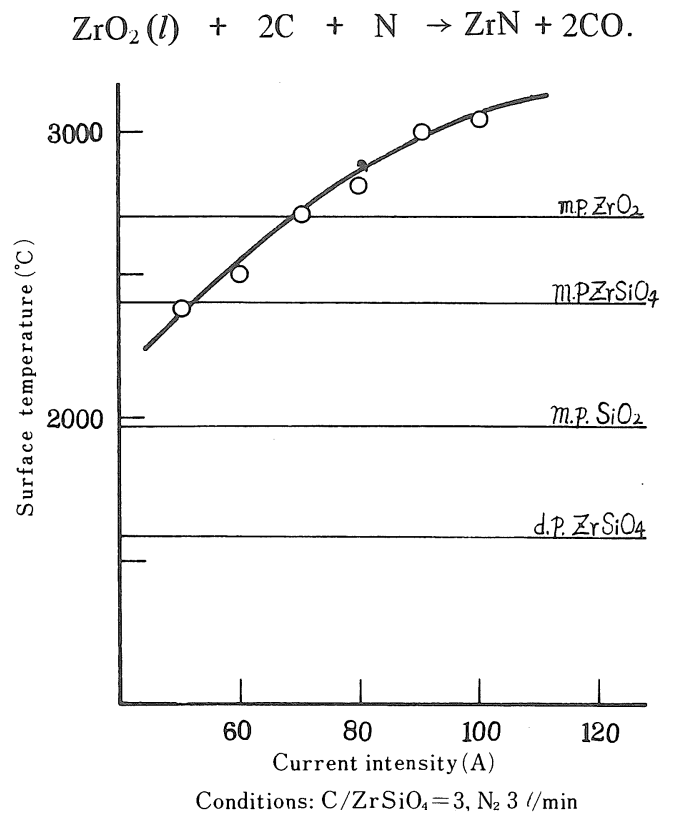

Fig. 28 Relation between surface temperature of $\mathrm{ZrSiO}_{4}$-graphite tablet and current intensity

\subsection{Formation of Zirconium Nitride by Nitriding Zirconium Sillicate ${ }^{7)}$}

2.5.1 Temperature measurement The surface temperature of the $\mathrm{ZrSiO}_{4}$-graphite mixture tablet under the nitrogen plasma jet was measured with a micro-pyrometer. The relation between the temperature of the surface of the tablet and the current intensity is shown in Fig. 28. The surface temperature was higher than the decomposition temperature of $\mathrm{ZrSiO}_{4}$ at the current intensity of $50 \mathrm{amp}$. The temperature raised with increasing current intensity, and when the current intensity came up to higher than 80 amp. the surface temperature was higher than the melting point of $\mathrm{ZrO}_{2}$.

2.5.2 Confirmation of products As nitrogen plasma jet reacted with the tablet, the metallic cake was formed on the graphite block and a yellow powder deposited on the copper coil.

By an X-ray diffraction, the cake was of $\mathrm{ZrN}, \mathrm{ZrC}$ and $\mathrm{SiC}$ in several cases. The powder deposited on the copper coil was not identified by an X-ray diffraction, and the powder may be amorphous or of very fine crystal. The powder was identified by means of an infrared absorption spectrum measurement and an electron diffraction. The infrared absorption spectra of the powder deposited on the coil are shown in Fig. 29. The band at $1,080 \mathrm{~cm}^{-1}$ was identified as an Si-O stretching vibration and that at $450 \mathrm{~cm}^{-1}$ was identified as an O-Si-O deformation vibration. The infrared band at $900 \mathrm{~cm}^{-1}$ was identified as an Si-N stretching vibration ${ }^{17}$ ). In Fig. 29, the infrared absorption spectra of

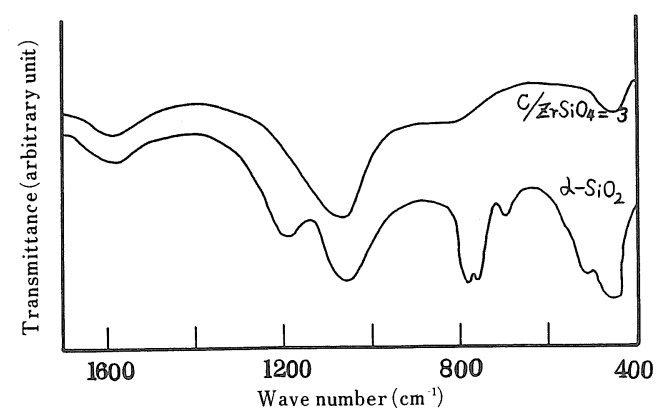

Fig. 29 Infrared absorption spectra of the powder deposited on the coil and $\alpha$-quartz 
$\alpha$-quartz was shown as an comparison. The powder obtained was different from $\alpha$-quartz. From an electron diffraction, the powder is identified as silicon, $\beta$-quartz or $\alpha$-SiC. It was considered that the powder was the mixture of fine crystals of various silicon oxides including $\mathrm{Si}_{3} \mathrm{~N}_{4}$ and $\mathrm{SiC}$.

2.5.3. Influence of the mixing ratio of carbon to $\left.\mathrm{ZrSiO}_{4}(\mathrm{C} / \mathrm{ZrSiO})_{4}\right)$ The influence of $\mathrm{C} / \mathrm{ZrSiO}_{4}$ to the reaction is shown in Fig. 30* $\mathrm{Zr}$ C.R. was maximum at $\mathrm{C} / \mathrm{ZrSiO}_{4}=3$. In Fig. 30 , the relation between $\mathrm{Zr} C \cdot R$. and $\mathrm{C} / \mathrm{ZrO}_{2}$ by nitriding $\mathrm{ZrO}_{2}$ is shown as an comparison. Both show a similar tendency.

Identified compounds in the cake are listed in Table 5. When $\mathrm{C} / \mathrm{ZrSiO}_{4}$ was smaller than 3, monoclinic $\mathrm{ZrO}_{2}$ was found with $\mathrm{ZrN}$, but when $\mathrm{C} / \mathrm{ZrSiO}_{4}$ was 3 the product was almost $\mathrm{ZrN}$. A solid solution of $\mathrm{ZrN}$ and $\mathrm{ZrC}$ was formed at $\mathrm{C} / \mathrm{ZrSiO}_{4}=4$, and when $\mathrm{C} / \mathrm{ZrSiO}_{4}$ exceeded 5 the product was $\mathrm{ZrC}$ containning $\mathrm{SiC}$. The infrared absorption spectra of the powder obtained by different $\mathrm{C} / \mathrm{ZrSiO}_{4}$ are shown in Fig.

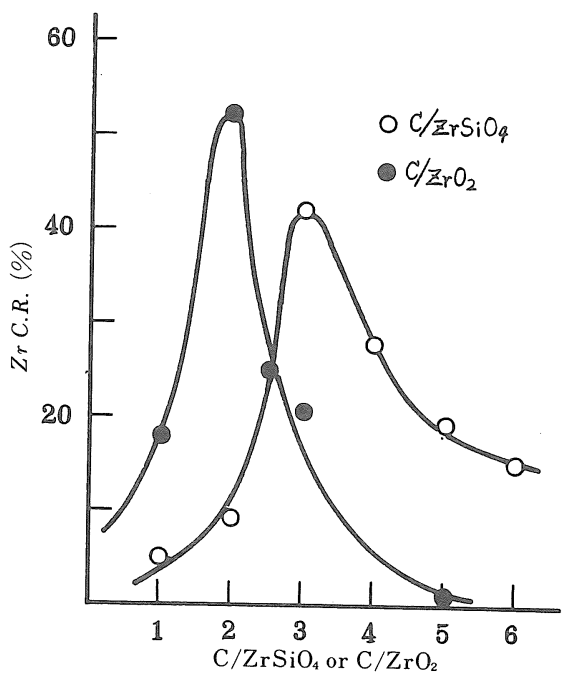

Reaction conditions: $80 \mathrm{~A}, \mathrm{~N}_{2} 3 \ell / \mathrm{min}, 1 \mathrm{~min}$

Fig. 30 Relation between $Z r C . R$. and $\mathrm{C} / \mathrm{ZrSiO}_{4}$

* In Fig. 30, $\mathrm{Z}_{\mathbf{r}}$ conversion rate $\left(\mathrm{Z}_{r}\right.$ C.R. $)$ is defined as follows.

Zr C.R. $=\left[\left(\mathrm{Z}_{\mathbb{r}}\right.\right.$ as $\mathrm{Z}_{\mathbb{r} N}$ in product $\left.\left.(\mathrm{g})\right) \cdot\right] /\left(\mathrm{Z}_{\mathbf{r}}\right.$ as $\mathrm{ZrSiO}_{4}$ in original tablet $\left.\left.(\mathrm{g})\right)\right] \times 100(\%)$
Table 5 Identified compounds in the cake obtained for various $\mathrm{C} / \mathrm{ZrSiO}_{4}$

\begin{tabular}{c|c}
\hline $\mathrm{C} / \mathrm{ZrSiO}_{4}$ & Identified compounds \\
\hline 0 & $\mathrm{ZrO}_{2}(\mathrm{~m})^{*}$ \\
1 & $\mathrm{ZrO}_{2}(\mathrm{~m}), \mathrm{ZrN}$ \\
2 & $\mathrm{ZrO}_{2}(\mathrm{~m}), \mathrm{ZrN}$ \\
3 & $\mathrm{ZrN}$ \\
4 & $\mathrm{ZrN}-\mathrm{ZrC}$ \\
5 & $\mathrm{ZrC}, \beta-\mathrm{SiC}$ \\
6 & $\mathrm{ZrC}, \beta-\mathrm{SiC}$ \\
\hline
\end{tabular}

* $\mathrm{ZrO}_{2}(\mathrm{~m}):$ monoclinic $\mathrm{ZrO}_{2}$

Reaction condition: 80A, $\mathrm{N}_{2} 3 \mathrm{l} / \mathrm{min}, 1 \mathrm{~min}$

31. In every case, infrared bands were observed at $1,080 \mathrm{~cm}^{-1}$. When $\mathrm{C} / \mathrm{ZrSiO}_{4}$ was 3 the band at $900 \mathrm{~cm}^{-1}$ was observed. When $\mathrm{C} / \mathrm{ZrSiO}_{4}$ exceeded 5 the band at $850 \mathrm{~cm}^{-1}$ that was indentified as an $\mathrm{Si}-\mathrm{C}$ stretching vibration was observed.

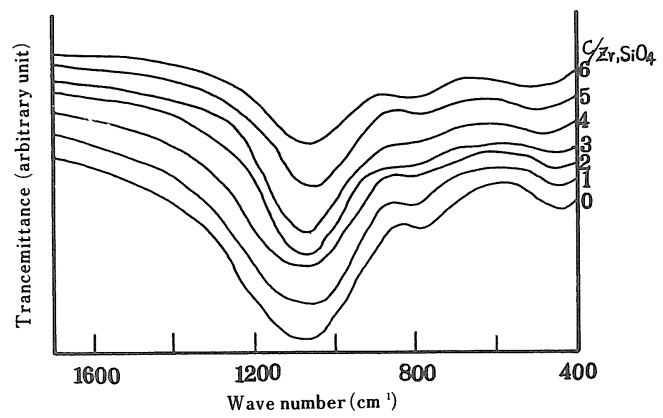

Fig. 31 Infrared absorption spectra of the powder deposited on the coil by various $\mathrm{C} / \mathrm{ZrSiO}_{4}$

\subsubsection{Influence factors on the formation} of $\mathbb{Z r N}$ Influences of various conditions such as the current intensity, the nitrogen flow rate and the reaction time to the formation of $\mathrm{ZrN}$ were examined.

The relation between $Z r \quad C_{0} R_{0}$ and the current intensity is shown in Fig. 32, and $Z r$ C.R. gradually increased with current intensity.

The relation between $Z r \quad C . R$. and the nitrogen flow rate is shown in Fig. 33, and $Z r$ $C . R$. gradually increased with increasing the 
nitrogen flow rate, and then $\operatorname{Zr} C . R$. was almost constant.

The relation between $Z r \quad C . R$. and the reaction time is shown in Fig. 34 . The reaction proceeded with increasing reaction time up to 60 sec.

In Figs. 32, 33 and 34, relations between $\mathrm{Zr}$

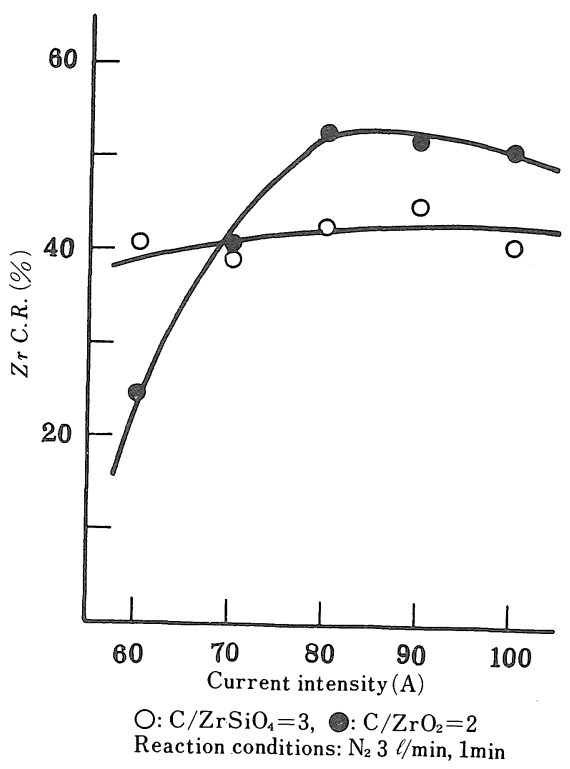

Fig. 32 Relation between $Z r$ C.R. and the current intensity

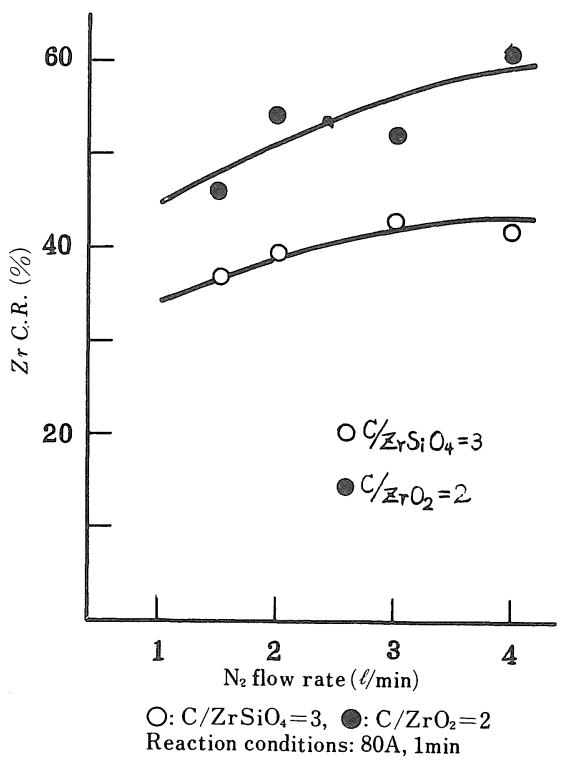

Fig. 33 Relation between $\mathrm{Zr}$ C.R. and the nitrogen flow rate

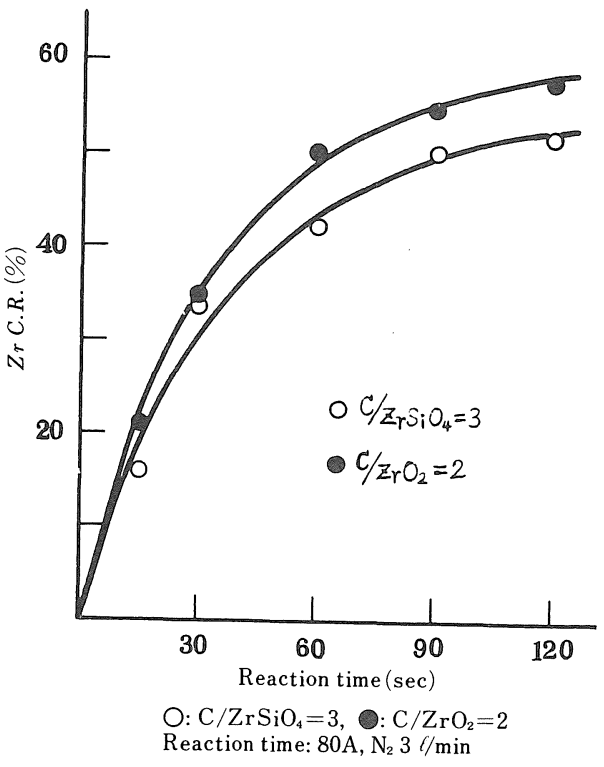

Fig. 34 Relation between $Z r$. C.R. and the reaction time

C.R. and various nitriding factors of $\mathrm{ZrSiO}_{4}$ showed a similar tendency to those of nitriding $\mathrm{ZrO}_{2}$.

2.5.5 -Discussion of mitriding of $\mathrm{ZrSiO}_{4} \quad \mathrm{As}$ mentioned previously ${ }^{1}$ ) nitrogen plasma jet is supposed to consist in mainly atomic nitrogen. Heavy heating by the plasma jet will cause the decomposition of $\mathrm{ZrSiO}_{4}$ to $\mathrm{ZrO}_{2}$ and $\mathrm{SiO}_{2}$. The nitriding of $\mathrm{ZrSiO}_{4}$ will proceed by the reaction between atomic nitrogen, $\mathrm{ZrO}_{2}, \mathrm{SiO}_{2}$ and graphite.

The temperature dependence of the free energy change for probable reaction of $\mathrm{ZrO}_{2}$ $\mathrm{SiO}_{2}-\mathrm{C}$ system and atomic nitrogen ${ }^{10}$ ) were calculated and are shown in Fig. 35. From Fig. 35, every reaction may proceed at above $2,500^{\circ} \mathrm{K}$ and $\mathrm{C} / \mathrm{ZrSiO}_{4}$ may affect to the reaction. When $\mathrm{C} / \mathrm{ZrSiO}_{4}$ is smaller than 3 main reaction may be $\mathrm{SiO}_{2}+\mathrm{C} \rightarrow \mathrm{SiO}+\mathrm{CO}$, on the other hand when $\mathrm{C} / \mathrm{ZrSiO}_{4}=3$ reactions as $\mathrm{ZrO}_{2}+2 \mathrm{C}+\mathrm{N}$ $\rightarrow \mathrm{ZrN}+2 \mathrm{CO}$ and $\mathrm{SiO}_{2}+2 \mathrm{C}+4 / 3 \mathrm{~N} \rightarrow 1 / 3$ $\mathrm{Si}_{3} \mathrm{~N}_{4}+2 \mathrm{CO}$ may also proceed. When $\mathrm{C} /$ $\mathrm{ZrSiO}_{4}$ exceeds $4, \mathrm{ZrO}_{2}+3 \mathrm{C} \rightarrow \mathrm{ZrC}+2 \mathrm{CO}$ and $\mathrm{SiO}_{2}+3 \mathrm{C} \rightarrow \mathrm{SiO}+2 \mathrm{CO}$ may also proceed.

From experimental results, when $\mathrm{C} / \mathrm{ZrSiO}_{4}$ was smaller than 2 the main product was $\mathrm{SiO}$. $\mathrm{ZrN}, \mathrm{SiO}$ and $\mathrm{Si}_{3} \mathrm{~N}_{4}$ were formed at $\mathrm{C} / \mathrm{ZrSiO}_{4}=$ 


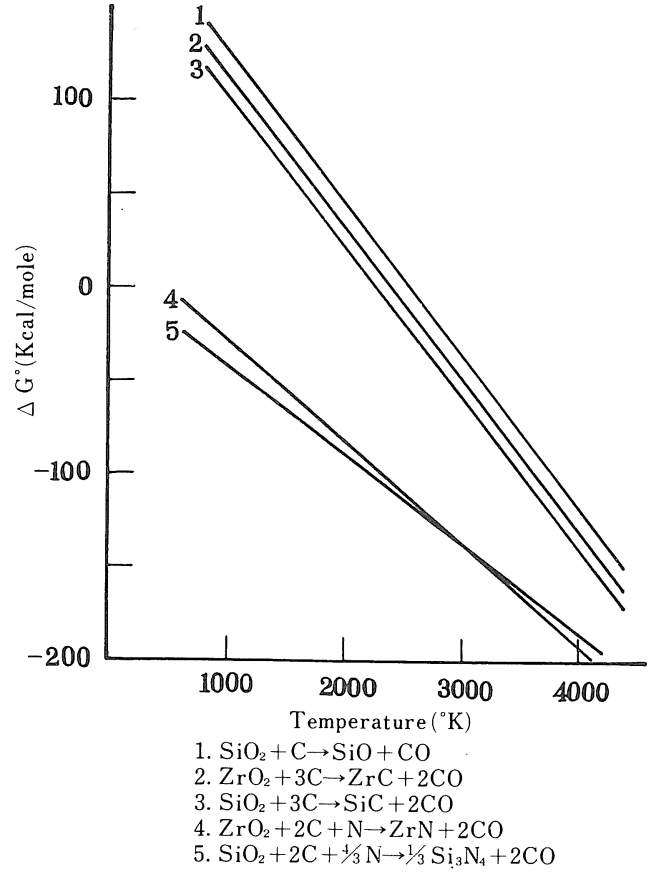

Fig. 35 Relation between $\Delta \mathrm{G}^{\mathrm{o}}$ of $\mathrm{ZrSiO}_{4}$ nitriding reaction and temperature.

3, and when $\mathrm{C} / \mathrm{ZrSiO}_{4}$ exceeded $4 \mathrm{ZrC}$ and $\mathrm{SiC}$ were formed. $\mathrm{SiO}$ and $\mathrm{Si}_{3} \mathrm{~N}_{4}$ are gaseous state at above $2,500^{\circ} \mathrm{K}$ and deposited on the copper coil by quenching. In this case, $\mathrm{SiO}$ changes to $\mathrm{SiO}_{2}$ and silicon by a disproportionation reaction at a temperature below $2,000^{\circ} \mathrm{K}$ and they might be amorphous with X-ray diffraction data.

The behaviour of zirconium in the reaction at $\mathrm{C} / \mathrm{ZrSiO}_{4}=3$ was similar to that of nitriding $\mathrm{ZrO}_{2}$ at $\mathrm{C} / \mathrm{ZrO}_{2}=2$. It is considered that $\mathrm{ZrO}_{2}$ and $\mathrm{SiO}_{2}$ react with carbon and nitrogen independently.

The optimum nitriding condition of zirconium silicate was $\mathrm{C} / \mathrm{ZrSiO}_{4}=3$ and the overall reaction may proceed in the following way,

$\mathrm{ZrO}_{2}+\mathrm{SiO}_{2}+3 \mathrm{C}+\mathrm{N} \rightarrow \mathrm{ArN}+\mathrm{SiO}+3 \mathrm{CO}$.

\subsection{Consideration of Nitrides Formation by Nitriding Oxides}

Various nitrides were formed by nitriding oxides and silicate by the nitrogen plasma jet. As nitriding of metal oxides and a silicate was difficult to carry out, it was necessary to add a small amount of carbon as a reductant.

Nitrogen plasma jet is supposed to consist in mainly atomic nitrogen. Heavy heating by nitrogen plasma jet will cause melting of oxides-graphite mixtures. Nitrides formation will proceed through there reaction between atomic nitrogen and molten oxides.

The mixing ratio of graphite to oxide affected the nitride formation. Intermediates such as a nonstoichiometric oxides and an oxycarbides were identified. The reduction of oxide by carbon should be carried out at a beginning of reaction, then the nitriding by atomic nitrogen was occurred.

From experimental results and thermodynamical consideration, the overall reaction may be carried out by the reaction,

$$
\mathrm{MO}_{\mathrm{x}}+\mathrm{xC}+\mathrm{nN} \rightarrow \mathrm{MN}_{\mathrm{n}}+\mathrm{xCO}
$$

The yields of nitrides were affected by stability of nitrides likewise in case of nitriding metals.

The nitriding of zirconium silicate in the same way as the case of metal oxides was studied as an application. $\mathrm{ZrN}$ was formed through the following reaction,

$\mathrm{ZrO}_{2}+\mathrm{SiO}_{2}+3 \mathrm{C}+\mathrm{N} \rightarrow \mathrm{ZrN}+\mathrm{SiO}+3 \mathrm{CO}$.

In this case, $\mathrm{ZrN}$ was formed as a molten state and $\mathrm{SiO}$ was formed as a gaseous state. Therefore, $\mathrm{SiO}$ was separated from $\mathrm{ZrN}$ and pure $\mathrm{ZrN}$ was obtained. This method will be applied to nitriding other silicates.

\section{Summary}

Nitrides formation by the reaction between nitrogen plasma jet and tablets made by various oxides as $\mathrm{Al}_{2} \mathrm{O}_{3}, \mathrm{TiO}_{2}$ and $\mathrm{ZrO}_{2}$, and graphite powder were also examined, and $\mathrm{AlN}, \mathrm{TiN}$ and $\mathrm{ZrN}$ were formed. The formation of nitrides will proceed by the reaction between the atomic nitrogen and the molten oxides. The mixing ratio of graphite to oxides affected the nitrides formation. Intermediates as nonstoichiometric oxides and oxycarbides were identified. The reduction of oxide by carbon should be carried out at a beginning of the reaction, then the 
nitriding by atomic nitrogen be occurred. The overall reaction may be carried out through the reaction,

$$
\mathrm{MO}_{\mathrm{x}}+\mathrm{xC}+\mathrm{nN} \rightarrow \mathrm{MN}_{\mathrm{n}}+\mathrm{xCO}
$$

The nitriding of zirconium silicate by the same way as the case of metal oxides was studied. $\mathrm{ZrN}$ was formed by the reaction,

$$
\mathrm{ZrO}_{2}+\mathrm{SiO}_{2}+3 \mathrm{C}+\mathrm{N} \rightarrow \mathrm{ZrN}+\mathrm{SiO}+3 \mathrm{CO}
$$

$\mathrm{ZrN}$ was formed.

\section{Literatures:}

1) O. Matsumoto, Y. Shirato, Y. Hayakawa, This Journal 37, (1969).

2) O. Matsumoto, Y. Shirato, M. Miyazaki, ibid. 36, 219 (1968).
3) O. Matsumoto, Y. Shirato, M. Miyazaki, Denki Kagaku 36, 41 (1968), (in Japanese).

4) O. Matsumoto, Y. Shirato, Denki Kagaku 36, 519 (1968), (in Japanese).

5) O. Matsumoto, ibid. 36, 877 (1968), (in Japanese).

6) I.E. Cambell, "High Temperature Technology" p. 175 (1956), The Electrochemical Society Inc., N.Y.

7) O. Matsumoto, Y. Shirato, Denki Kagaku 38, 168 (1970), (in English).

8) J. M. Hall, AD 431,797 (1963).

9) L. M. Dreger, V. V. Davota, J. L. Margrave, J. Phys. Chem. 66, 1556 (1962).

10) JANAF, "Thermochemical Table" (1965), Dow Chemical Corp., Midland, Michigan.

11) D. Douglas, Met. Soc. Conf. 8, 785 (1961).

12) O. Matsumoto, This Journal 37, 199 (1969).

13) R. Ruh, J. Am. Ceram. Soc. 50, 257 (1967).

14) C. F. Gravin, ibid. 50, 288 (1967).

15) J. P. Guerlet, P. Leur, Compt. rend. 260, 899 (1965).

16) J. G. Gilles, Bull. Soc. Chim. France $1962,2118$.

17) M. J. Grieco, F. L. Worthy, B. Schwartz, J. Electrochem. Soc. 115, 525 (1968). 